\title{
混合補間要素を用いた非圧縮粘性流れ解析 のための高精度安定化有限要素法
}

\author{
樫山和男 1 ・猪股 渉 2 \\ 1 正会員 工博 中央大学助教授 理工学部土木工学科 ( $\overline{1} 112-8551$ 東京都文京区春日 1-13-27) \\ 2正会員 工修 東京ガス (株) 商品技術開発部 (テ 230-0045 神奈川県横浜市鶴見区末広町 1-7-7)
}

\begin{abstract}
本論文は, 流速双 1 次/圧力区分 0 次 $(\mathrm{Q} 1 / \mathrm{P} 0)$ の混合補間要素を用いた, 非圧縮粘性流れ解析のための高精度 な安定化有限要素法の提案を行うものである. 本手法は, 空間の離散化に対してSUPG 法と圧力安定化行列を用 い, 時間の離散化に対しては修正準陰解法を用いるものである. 本手法は, 従来提案されている代表的な安定化 有限要素法である GLS 法やSUPG/PSPG 法と理論的に等価であり, それらに比べてより簡便に安定化が図れ, かつ高精度で計算効率に優れた手法であることを，代表的な数值解析例に対する比較計算により示している。
\end{abstract}

KeyWords : incompressible Navier-Stokes flows, Q1/P0 mixed finite element method, SUPG method, pressure stabilization matrix, modified semi-implicit method

\section{1. はじめに}

近年, 超長大橋や超高層ビルなど構造物の大型化が 進む中で，構造物周辺での風の流れの挙動や構造物に 働く流体力を正確に評価することが益々重要となって いる.これまで，これらの評価法としては，主として 風洞実験が用いられてきたが，近年の計算機性能およ び計算技術の飛躍的な進歩により，数值計算により評 価の一部を行うことが可能となり，多くの数值計算手 法が提案されている.これらの数值計算手法のほとん どは，構造格子を基本とする有限差分法，非構造格子 を基本とする有限体積法や有限要素法のいずれかに基 づいている，本論文では，任意形状への適合性及び境 界条件の処理に優れており，複雑形状を有する実際問 題の解析に有効となり得る有限要素法に着目する.

非圧縮粘性流れの基礎方程式である Navier-Stokes 方 程式を有限要素法により解く際に, 数值解が不安定に振 動する場合がある．その主な原因としては，次の二つの 点が挙げられる. 原因の一つ目は, 高 Reynolds 数流れ になった場合の移流項の卓越に起因し，通常の Galerkin 法では有限差分法の中心差分と等価となるため, 数值解 は不安定に振動する. 従って，これを防ぐためには移流 項に対し何らかの安定化 (風上化) を施す必要がある. 原 因の二つ目は，流速・圧力の補間関数の組み合わせが下 限上限条件 (inf-sup condition，または Babuška-Brezzi condition) を満たさない場合であり，この場合には，解 が安定に求まる保証はない1)-3).

本論文は, 定式化やプログラミング等の取り扱い が容易な流速双 1 次/圧力区分 0 次 $(\mathrm{Q} 1 / \mathrm{P} 0)$ 要素を用
いた, 非圧縮粘性流れ解析のための高精度で計算 効率に優れた安定化有限要素法の提案を行うもの である．前記の数值不安定性を取り除く方策とし て, 移流項の卓越による数值不安定性に対しては, SUPG(streamline upwind/Petrov-Galerkin) 法4),5) を 適用することにより安定化を図るものとする．また， 下限上限条件を満たさない事による数值不安定性に関 しては, 従来の安定化有限要素法から導かれる圧力の 安定化に奇与するPSPG(pressure stabilizing/PetrovGalerkin) 項と等価な圧力安定化行列 (pressure stabi-

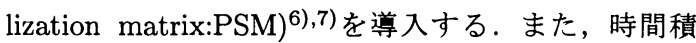
分法としては，修正準陰解法 ${ }^{12)}$ (MSI(modified semiimplicit) 法)を適用する.これらの手法は，いずれも単 体としては既存の手法であるが，これらを組み合わせ ることにより安定で高精度な手法となり得る。

本論文では，提案する組み合わせ手法 (SUPG/PSM +MSI法)が従来提案されている代表的な安定化有限 要素法であるGLS(Galerkin least squares)法8),9)や SUPG/PSPG 法 ${ }^{10)}$ と理論的に等価であり, Q1/P0 要素 のための安定化有限要素法となることを示すとともに, 計算効率の向上化 (省メモリー化と高速化) 法について 述べる. そして, 本手法の数值流体解析手法としての 有効性を検討するために，いくつかの代表的な数值解 析例に対して，本手法と従来提案されている種々の安 定化の手法および時間積分法との比較を行った．なお， 数值解析例としては, ベンチマーク問題として孤立渦 問題及びCavity 内流れ問題を，また 3 次元高 Reynolds 数流れ問題への適用性および有効性の確認として円柱 周りの流れ解析を取り上げた. 


\section{2. 基礎方程式と境界条件}

非圧縮粘性流れの場を支配する基礎方程式は，NavierStokes の運動方程式 (1) と連続式 (2) で表される.

$$
\begin{gathered}
\frac{\partial u_{i}}{\partial t}+u_{j} u_{i, j}+p_{, i}-\frac{1}{R e} u_{i, j j}=0 \quad \text { in } \Omega \\
u_{i, i}=0 \quad \text { in } \Omega
\end{gathered}
$$

ここで,,$_{i}$ は $i$ 方向の偏微分, $u_{i}$ は $i$ 方向の速度成 分, $p$ は圧力, $\operatorname{Re}(=U D / \nu)$ は Reynolds 数, $\Omega$ は境界 $\Gamma$ で囲まれた解析領域を示す．また，このときの境界 条件は,

$$
\begin{gathered}
u_{i}=\hat{u}_{i} \quad \text { on } \Gamma_{g} \\
\left(-p \delta_{i j}+\frac{1}{R e} u_{i, j}\right) n_{j}=\hat{t}_{i} \quad \text { on } \Gamma_{h}
\end{gathered}
$$

で表される.ここで, $n_{j}$ は境界外向き単位法線ベクトル， $\delta_{i j}$ はKroneckerの $\delta, \Gamma_{g}$ と $\Gamma_{h}$ はそれぞれ, Dirichlet $(g)$ と Neumann $(h)$ の境界条件が与えられる境界を示す。

\section{3. $\mathrm{Q} 1 / \mathrm{P} 0$ 要素のための安定化有限要素法}

有限要素法における安定化法として，いくつかの手 法が提案されている. 代表的な方法としては，時間積分 の精度を 2 次及び 3 次と高めることにより，風上化の効 果を得る BTD 法 ${ }^{13)}$ や Taylor-Galerkin 法 ${ }^{11)}$ がある.ま た，風上側の重みを増すことにより風上化を行う PetrovGalerkin型の手法が数多く提案されている4)-10). 中で もSUPG 法4),5) は，テンソル型の人工拡散係数により， 流れ方向にのみ人工拡散を付加させる高精度な手法と して広く用いられている. しかし,これらの方法は移流 の卓越に対してのみの安定化であり，下限上限条件に よる制限を回避できないため，用いる要素によっては 圧力振動が発生する.Fig.1は，代表的な四角形要素に 対して，それぞれが下限上限条件を満足するか否かを 示したものである. 図中，○印が流速の評価点，×印が 圧力の評価点を示す. 従って, 流速と圧力を共に双 1 次 で補間する $\mathrm{Q} 1 / \mathrm{Q} 1$ 要素や，本論文で用いる流速を双 1 次，圧力を区分 0 次で補間する $\mathrm{Q} 1 / \mathrm{P} 0$ 要素は，この条 件を満足しないことになる.

そこで，近年，前記の二つの数值不安定性を同時に 克服することを目的として，SUPG 法に改良を加えた 安定化有限要素法である GLS 法8),9) やSUPG/PSPG 法 10)などが開発されている. それらの方法は, SUPG 法に より得られる項の他に, さらに新たな安定化の項 (PSPG 項)を導入した形となっており，その結果，SUPG 項に より移流の卓越に対しての安定化，PSPG 項により下 限上限条件の回避を実現している。 しかし，GLS 法に よる定式化に $\mathrm{Q} 1 / \mathrm{P} 0$ 要素を用いる場合は，高次微分項 を考慮できないために結局 SUPG 法に帰着し，PSPG 項が表現されないことになる．そのため何らかの形で

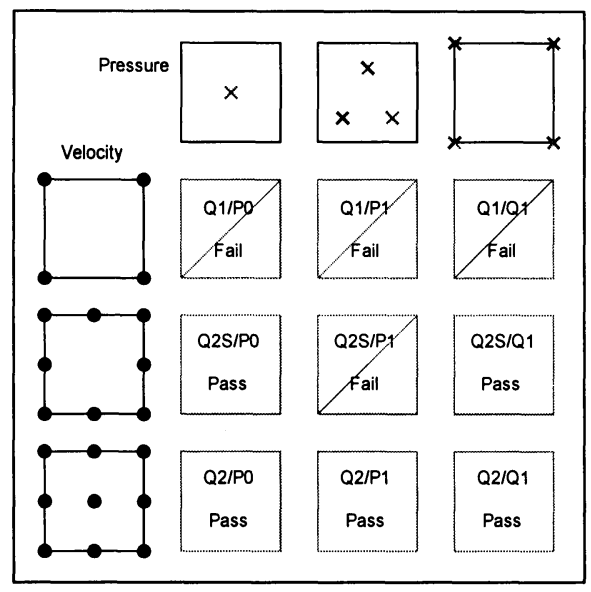

Fig.1 Finite element mesh for incompressible N-S flow

PSPG 項を表現する必要があり, 本論文ではPSPG 項 と同じ意味合いを持つ圧力安定化行列を適用すること とする

\section{（1） SUPG 法による移流卓越に対する安定化}

一つ目の問題点, 移流卓越による数值不安定性に対 しては，SUPG 法を適用することにより安定化を図る こととする. SUPG 法では, Galerkin 法の重み関数 $w_{i}$ に要素間で不連続な関数 $\delta_{i}$ を付加させた次のような重 み関数を用いる.

$$
w_{i}+\delta_{i}, \quad \delta_{i}=\tau u_{j} w_{i, j}
$$

$\tau$ は時間の次元を持つ上流化パラメーターであり，要 素サイズ $h$ を流速 $\left\|u_{i}^{h}\right\|$ で割った值を基本とし様々な 与え方が提案されている4),5),10). 最近では, 要素ごと に決められる要素 Reynolds 数

$$
R e_{u}=\frac{\left\|u_{i}^{h}\right\|}{2 \nu}
$$

の関数で与えられているものがほとんどであり，本論 文でも同様に次のように与えている21).

$$
\begin{aligned}
\tau & =\left(\left(\frac{2\left\|u_{i}^{h}\right\|}{h}\right)^{2}+\left(\frac{4 \nu}{h^{2}}\right)^{2}\right)^{-1 / 2} \\
& =\frac{h}{2\left\|u_{i}^{h}\right\|}\left(1+\left(\frac{1}{R e_{u}}\right)^{2}\right)^{-1 / 2}
\end{aligned}
$$

ここで, $\nu$ は渦動粘性係数， $h$ は要素サイズである. $h$ の定義としては，ここでは簡単のため要素の面積と同 じ面積を持つ円の直径を与えている.

運動方程式(1)に対してはSUPG 法による重み関数 $w_{i}+\delta_{i}$ を, 連続式 (2) に対してはGalerkin 法による重 み関数 $q$ を適用することにより弱形式を導くと次のよ 
うになる。

$$
\begin{aligned}
& \int_{\Omega} w_{i}\left(\frac{\partial u_{i}}{\partial t}+u_{j} u_{i, j}\right) d \Omega \\
& \quad+\int_{\Omega} w_{i, j}\left(-p \delta_{i j}+\frac{1}{R e} u_{i, j}\right) d \Omega+\int_{\Omega} q u_{i, i} d \Omega \\
& \quad+\sum_{e=1}^{n_{e l}} \int_{\Omega^{e}} \delta_{i}\left(\frac{\partial u_{i}}{\partial t}+u_{j} u_{i, j}+p_{, i}-\frac{1}{R e} u_{i, j j}\right) d \Omega \\
& =\int_{\Gamma_{h}} w_{i}\left(-p \delta_{i j}+\frac{1}{R e} u_{i, j}\right) n_{j} d \Gamma
\end{aligned}
$$

ここで; $\delta_{i}$ の要素間での不連続性を考慮し， $\delta_{i}$ の掛かっ た部分は部分積分を行わないで計算する。これにより， Q1/P0 要素を用いた定式化では, SUPG 項 (第4 項)の うち圧力項と拡散項は考慮されないことになる．弱形 式(8)において, Q1/P0要素を用いて流速を双 1 次, 圧 力を区分 0 次で補間すると次のような有限要素方程式が 導かれる。

$$
\begin{gathered}
M \frac{\partial u_{i}}{\partial t}+\boldsymbol{K}\left(u_{j}\right) u_{i}-C p+\frac{1}{R e} S u_{i}=\mathbf{o} \\
C^{T} u_{i}=\mathbf{o}
\end{gathered}
$$

ここで, $M, K, S, C, C^{T}$ はそれぞれ質量, 移流, 拡散, 勾配, 発散行列であり, 質量行列と移流行列に関 しては [Galerkin 項]+[SUPG 項] という二つの行列から 構成されている. これらの係数行列の積分方法として, 数值積分に代わり解析的な積分公式を用いることによ り高速化を図っている(14).この方法は，Jacobianの行 列式のみを 1 点求積法により求め, 残りの部分を解析的 に計算することにより，係数行列の積分を効率よく行 えるというものである.

\section{（2）圧力安定化行列による下限上限条件の制限に対す る安定化}

二つ目の問題点，下限上限条件の制限に対しては，圧 力安定化行列を適用することにより安定化を図ること とする. 圧力安定化行列を導くために, 運動方程式(1) と連続式 (2) を有限要素法により直接離散化した際に構 成される連立 1 次方程式を考える. 離散化された連立 1 次方程式は陽解法・陰解法ともに次のような形で与え られる。

$$
\left[\begin{array}{cc}
\boldsymbol{B} & -C \\
C^{T} & \mathbf{0}
\end{array}\right]\left\{\begin{array}{c}
u_{i}^{n+1} \\
\Delta t p^{n+1}
\end{array}\right\}=\left\{\begin{array}{c}
b_{i}^{n} \\
\mathbf{o}
\end{array}\right\}
$$

ここで，B は陽解法を用いた場合は集中化質量行列 $M_{L}$, 陰解法の場合は移流拡散行列 $[M+K+S]$ とな る. また, $b_{i}^{n}$ は運動方程式の既知項をまとめたもので ある。

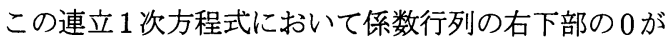
問題となり, 流速・圧力の補間関数の組合せによっては 方程式が正則にならずに圧力振動が生じる. それを避け るために, 右下の0行列部分にPSPG 法により生成さ

\begin{tabular}{|c|c|c|}
\hline 1 & 2 & 3 \\
\hline 4 & 8 & 6 \\
\hline 7 & 8 \\
\hline
\end{tabular}

Fig.2 2-D mesh to explain the stabilization matrix

れる項と同じ意味合いを持つ拡散型の行列 $\boldsymbol{D}$ を導入す るというのが圧力安定化行列の考え方である. Hughes

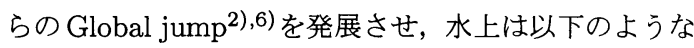
安定化行列を提案した 7 .

いま, その安定化行列をFig.2のような 9 の要素から なる 2 次元メッシュの場合の要素 5 について示すと,

$$
\begin{aligned}
\sum_{k} D_{5 k} p_{k}= & a_{5} a_{2}\left(p_{5}-p_{2}\right)+a_{5} a_{4}\left(p_{5}-p_{4}\right) \\
& +a_{5} a_{6}\left(p_{5}-p_{6}\right)+a_{5} a_{8}\left(p_{5}-p_{8}\right) \\
=a_{5} & \left\{\left(a_{2}+a 4+a 6+a 8\right) p_{5}\right. \\
& \left.-a_{2} p_{2}-a_{4} p_{4}-a_{6} p_{6}-a_{8} p_{8}\right\}
\end{aligned}
$$

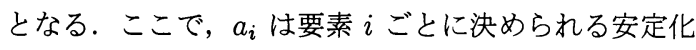
パラメーターで次のように与えている.

$$
a_{i}=\alpha \sqrt{\left(\boldsymbol{C}^{T} \boldsymbol{B}_{d}^{-1} \boldsymbol{C}\right)_{i i}}
$$

ここで, $\boldsymbol{B}_{d}$ は行列 $\boldsymbol{B}$ の対角部であり， $\alpha$ は安定化の 度合いを決める無次元パラメーターである. 本論文中 では， $\alpha$ の值は数值実験により安定性を確認し， 2 次元 の場合は $0.1,3$ 次元の場合は 0.25 を用いている.

この圧力安定化行列が $\mathrm{Q} 1 / \mathrm{P} 0$ 要素のための $\mathrm{PSPG}$ 項 となり, SUPG法と併用することにより Q1/P0 要素の ための安定化有限要素法 (SUPG/PSM 法) が導かれる. この手法はSUPG/PSPG 法と同様に安定化項が構成さ れることにより, 二つの問題点を同時に克服できるこ とになる. また, 他の安定化有限要素法と比べて定式 化・プログラミングがより簡便に行える手法である.

\section{4. 修正準陰解法による時間方向離散化}

SUPG/PSM 法により空間離散化された運動方程式 (9) と連続式 (10)の時間積分法としては, 修正準陰解法 12）を適用する. 修正準陰解法では, 運動方程式に関し て流速を陽的，圧力を陰的に，連続式に関しては陰的 に取り扱うことにより次のような式を導出する.

$$
\begin{gathered}
\frac{M_{c} u_{i}^{n+1}-M_{c} u_{i}^{n}}{\Delta t}+K\left(u_{j}^{n}\right) u_{i}^{n} \\
-M_{c} M_{L}^{-1} C p^{n+1}+\frac{1}{R e} S u_{i}^{n}=\mathbf{o} \\
C^{T} u_{i}^{n+1}+D \Delta t p^{n+1}=\mathbf{o}
\end{gathered}
$$


ここで， $M_{c}$ はConsistentな質量行列， $M_{L}$ は集中化 質量行列， $D$ は先に述べた圧力安定化行列である。 な お，離散化された運動方程式(9)において，通常得られ る圧力項 $\boldsymbol{C} \boldsymbol{p}^{n+1}$ に $\boldsymbol{M}_{c} \boldsymbol{M}_{L}^{-1}$ を掛けて近似するのが Gresho らの修正準陰解法の特徵となっている.この近 似により得られた式(14)は，さらに以下のように書き換 えることができ，移流項・拡散項に関しては Consistent な質量行列, 圧力項に関しては集中化質量行列という ように二種類の質量行列を用いて解くことになる.

$$
\begin{aligned}
\frac{u_{i}^{n+1}-u_{i}^{n}}{\Delta t} & +M_{c}^{-1} K\left(u_{j}^{n}\right) u_{i}^{n} \\
& -M_{L}^{-1} C p^{n+1}+\frac{1}{R e} M_{c}^{-1} S u_{i}^{n}=\mathbf{0}
\end{aligned}
$$

以上により得られた運動方程式と連続式に対する有限 要素方程式(14),（15) を連立することにより，次のよ うな連立 1 次方程式が得られる。

$$
\left[\begin{array}{cc}
M_{c}-M_{c} M_{L}^{-1} C \\
C^{T} & D
\end{array}\right]\left\{\begin{array}{c}
u_{i}^{n+1} \\
\Delta t p^{n+1}
\end{array}\right\}=\left\{\begin{array}{c}
b_{i}^{n} \\
0
\end{array}\right\}
$$

ここで， $b_{i}^{n}$ は運動方程式の既知項をまとめたもので あり

$$
b_{i}^{n}=M_{c} u_{i}^{n}-\Delta t\left(K\left(u_{j}^{n}\right) u_{i}^{n}+\frac{1}{R e} S u_{i}^{n}\right)
$$

となっている. 式(17)において, 記憶容量低減のため に圧力の部分を掃き出すと，次のような圧力のPoisson 方程式を導くことが出来る.

$$
\left(C^{T} M_{L}^{-1} C+D\right) \Delta t p^{n+1}=-C^{T} M_{c}^{-1} b_{i}^{n}
$$

ここで, 圧力の離散化に先の近似を用いたため, Poisson 方程式(連続式)を解く際には集中化した質量行列 $M_{L}$, 右辺の既知項 (運動方程式) を解く際には Consistent な 質量行列 $M_{c}$, というように二種類の質量行列を矛盾 なく用いることが可能となる。この点が通常の淮陰解 法との違いであり, 通常の準陰解法では式 (19)の右辺 項も集中化質量行列により解かれる.

なお，圧力のPoisson 方程式を解く際にはElementby-Element 共役勾配法 (SCG 法) ${ }^{15)}$ を用いている.こ の方法は，共役勾配法によってPoisson 方程式を解く際 に毎ステップ行う以下の繰り返し計算

$$
\omega=\left(C^{T} M_{L}^{-1} C\right) \phi
$$

を全体行列を組み立てないで $\boldsymbol{C}$ の要素行列 $\boldsymbol{C}^{e}$ を用い て以下のように段階的に行うというものである.これ により, 記憶容量の低減および計算の高速化が可能と なる。

$$
\begin{aligned}
\boldsymbol{\theta} & =\sum_{e}\left(C^{e} \phi\right) \\
\varphi & =M_{L}^{-1} \boldsymbol{\theta} \\
\boldsymbol{\omega} & =\sum_{e}\left(C^{e T} \varphi\right)
\end{aligned}
$$

ここで, 要素行列 $\boldsymbol{C}^{e}$ は 2 次元計算では各方向に $4 つ の$ 成分を持つ行列 (列ベクトル) であり, 式 (21c),(21b), (21c) を解くには 1 要素あたり 8 成分 (3次元計算の場合 は 24 成分) を記憶させるだけでよい，従って，問題が大 規模になっても要素数に比例しただけの記憶容量で計 算が行えるため，大規模計算に対して有効な方法であ ると言える.

\section{GLS 法との対応関係}

ここでは，本論文で提案する $\mathrm{Q} 1 / \mathrm{P} 0$ 要素のための安 定化有限要素法であるSUPG/PSM 法と，代表的な安定 化有限要素法である GLS 法を対比させることにより各 安定化項の効果を示すこととする. GLS 法8),9) はSUPG 法を発展させた安定化有限要素法であり，以下のよう に, 安定化の項が運動方程式 (1) と連続式 (2) の最小 2 乗形式になるような重みを与えることにより弱形式を 導<.

$$
\begin{aligned}
& \int_{\Omega} w_{i}\left(\frac{\partial u_{i}}{\partial t}+u_{j} u_{i, j}\right) d \Omega \\
& +\int_{\Omega} w_{i, j}\left(-p \delta_{i j}+\frac{1}{R e} u_{i, j}\right) d \Omega+\int_{\Omega} q u_{i, i} d \Omega \\
& +\sum_{e=1}^{n_{e l}} \int_{\Omega^{e}} \tau_{m}(\underbrace{\frac{\partial w_{i}}{\partial t}}_{(4-1)}+\underbrace{u_{j} w_{i, j}}_{(4-2)}+\underbrace{q_{, i}}_{(4-3)}-\underbrace{\frac{1}{R e} w_{i, j j}}_{(4-4)}) \\
& +\sum_{e=1}^{n_{e l}} \int_{\Omega^{e}} \tau_{c}\left(w_{j, j} u_{i, i}\right) d \Omega \\
& =\int_{\Gamma_{h}} w_{i}\left(-p \delta_{i j}+\frac{1}{R e} u_{i, j}\right) n_{j} d \Gamma
\end{aligned}
$$

ここで， $\tau_{m} ， \tau_{c}$ はそれぞれ運動方程式，連続式に対す るパラメーターであり, 次のように与えている21).

$$
\begin{gathered}
\tau_{m}=\left(\left(\frac{2\left\|u_{i}^{h}\right\|}{h}\right)^{2}+\left(\frac{4 \nu}{h^{2}}\right)^{2}\right)^{-1 / 2} \\
\tau_{c}=\lambda\left\|u_{i}^{h}\right\| z
\end{gathered}
$$

ここで, $\lambda, z$ はそれぞれ

$$
\begin{gathered}
\lambda=\frac{1}{2} \\
z\left(R e_{u}\right)= \begin{cases}R e_{u} / 3, & 0 \leq R e_{u} \leq 3 \\
1, & 3<R e_{u}\end{cases}
\end{gathered}
$$

としている. $R e_{u}$ は要素 Reynolds 数であり, SUPG 法 の場合と同様に式(6)に従って与える。

式 (22) において第 4 項と第 5 項が安定化の効果を生 むわけであり，特に重要な働きをする第 4 項は以下のよ うな効果を与える。 
4-1 項: 通常重み関数 $w_{i}$ は時間 $t$ の関数ではないので, $\partial w_{i} / \partial t$ は 0 となる. 時間方向にも有限要素法を適 用する Space-time 法 ${ }^{16)}$ で離散化する場合のみ時間 の関数 $w_{i}(t)$ となり，この項を考慮できる.

4-2 項: SUPG 項.

4-3 項: PSPG 項. この項が連続式に加わることにより, 下限上限条件の制限により生じる圧力振動を回避 できるようになる. しかし， Q1/P0 要素の場合, 圧 力を区分 0 次で補間しているためにこの項は 0 とな

る.このため, 本手法では圧力安定化行列を導入 している.

4-4 項: 2 次以上で流速を補間しない場合は考慮できな い. したがって, $\mathrm{Q} 1 / \mathrm{Q} 1(\mathrm{P} 1 / \mathrm{P} 1)$ 要素や $\mathrm{Q} 1 / \mathrm{P} 0$ 要 素を用いる場合は 0 となる.

これらの中で重要な意味を持つ項は, 4-2 項 (SUPG 項) と 4-3 項 (PSPG 項) であり，この二つの項がそれぞれ移 流の卓越，下限上限条件による数值振動を押さえる役 割を果たす. 要するに, この二つの項により安定化が 可能になるわけであり, この点に着目したのが SUPG 法とPSPG 法を併用させる SUPG/PSPG 法である．同 様に本論文で提案する SUPG/PSM 法もこの二つの項 と等価な項を構成することにより安定化が図れる手法 となっている.

\section{6. 数值解析例}

本論文で提案した，Q1/P0要素のための安定化有限 要素法の有効性を検討するために, ベンチマーク問題 として孤立渦問題及びCavity 内流れ問題を, また 3 次 元高 Reynolds 数流れ問題への適用性, 有効性の確認と して円柱周りの流れ解析を取り上げる.

\section{(1) 孤立渦問題}

最初のベンチマーク問題として，孤立渦問題5)を 取り上げる.この問題の目的は，本論文で提案する SUPG/PSM+MSI 法と他の様々な安定化法，またそれ に適用する時間積分法がどの程度の精度を有するかを比 較検討することにある. Fig.3に示すように正方形領域 を 20 分割し, 初期条件を $u_{\theta}=\{5 r$ for $r<0.2,2-5 r$ for $0.2<r<0.4,0$ for $r>0.4\}$ とする $R e=10^{8}$ の渦 を強制的に発生させる．流れが非粘性に近いので数值 解が初期条件を保つ手法ほど, 減衰の少ない高精度な 手法であると言える．そこで各手法により無次元時間 $t=3$ まで解析を行い, その際にどの程度解が初期条件 を保持しているかを確かめることにより各手法の散逸 誤差の比較を行った. なお，解析に用いる安定化法と時 間積分法は Table 1に示すような 9 種類の組合せを用い た。 また, 時間刻み幅 $\Delta t$ は陽解法である修正淮陰解法
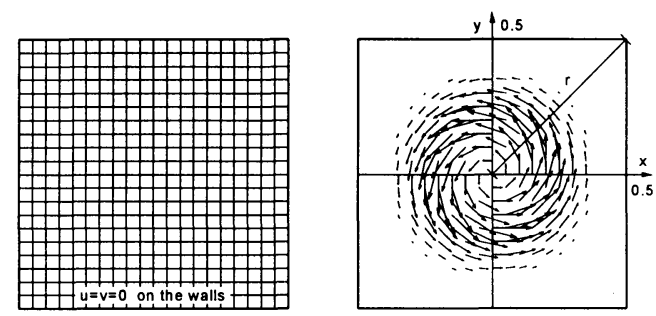

Fig.3 Finite element mesh and initial condition

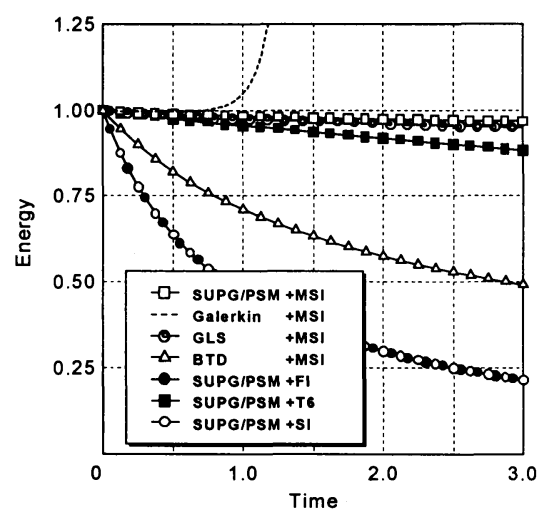

Fig.4 Time history of kinetic energy

Table 1 Comparison of kinetic energy at $t=3$

\begin{tabular}{|c|l|l|r|}
\hline & Space & Time & Energy at $t=3$ \\
\hline \hline & \multicolumn{4}{|l|}{ Exact solution } & 1.000 \\
\hline 1. & SUPG/PSM & MSI & 0.958 \\
\hline 2. & Galerkin & MSI & over flow \\
\hline 3. & GLS & MSI & 0.949 \\
\hline 4. & BTD & MSI & 0.491 \\
\hline 5. & TG & MSI & 0.491 \\
\hline 6. & SUPG/PSM & FI & 0.214 \\
\hline 7. & SUPG/PSM & CN & 0.215 \\
\hline 8. & SUPG/PSM & T6 & 0.883 \\
\hline 9. & SUPG/PSM & SI & 0.218 \\
\hline
\end{tabular}

(MSI 法) を適用する場合の限界值となる 0.025 (Courant 数=0.5) を用いて全ケースの解析を行った.

Fig.4に運動エネルギー（全要素の運動エネルギーの 総和を初期条件のそれで基準化したもの) の時刻歴を示 す. また, Table 1に, $t=3$ の時の運動エネルギーの值 を, Fig.5に同じく $t=3$ の時の渦度の鳥瞰図を示す.こ れらの結果から, SUPG/PSM 法の時間積分に修正淮陰 解法を適用した本手法と，T6 formulation を適用した場 合, また GLS 法による結果が初期の渦の形状とピーク值 を最もよく保ち，減衰を押さえているのが分かる．しか し, Gresho らの提案している修正準陰解法の元来の形で ある, BTD 法に修正準陰解法を適用した場合の結果は初 


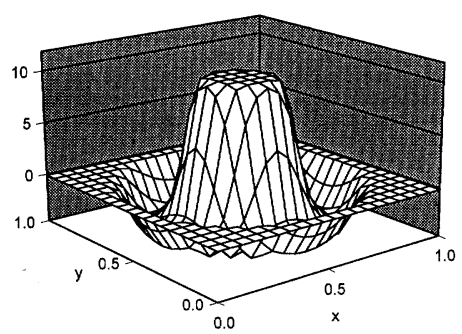

initial condition

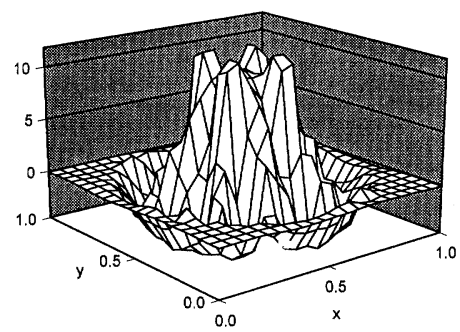

(2) Galerkin

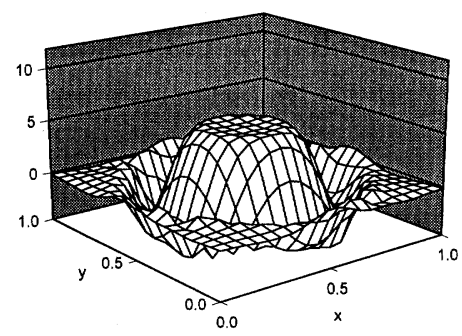

(4) BTD

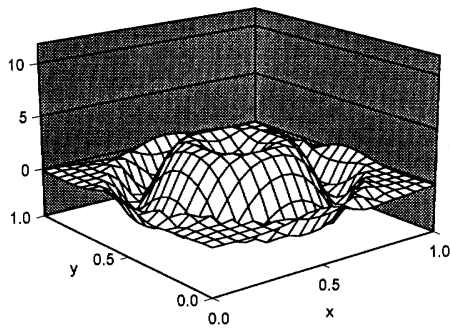

(6) SUPG/PSM+FI

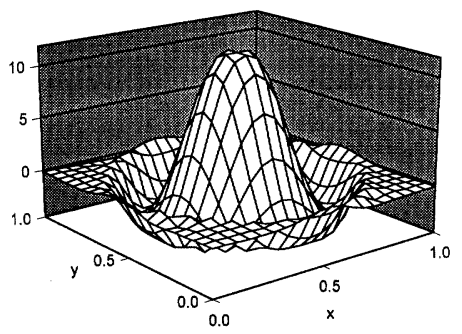

(8) SUPG/PSM+T6

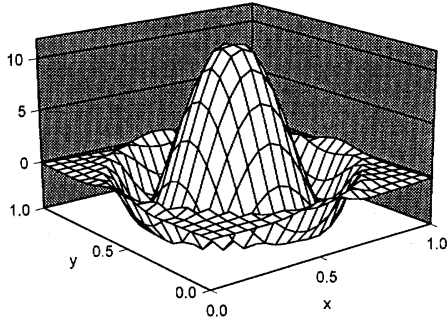

(1) present method(SUPG/PSM+MSI)

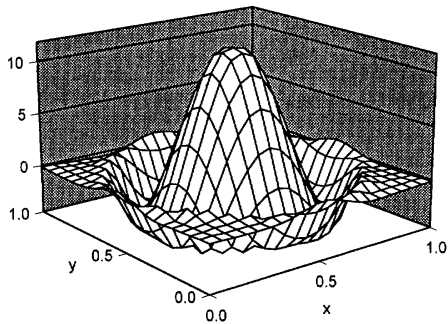

(3) GLS

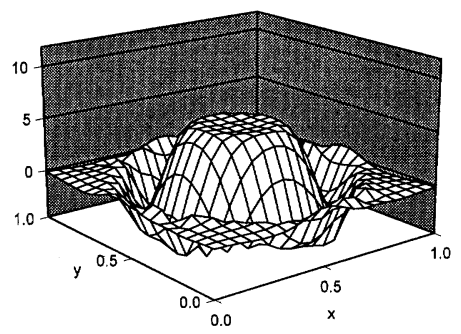

(5) TG

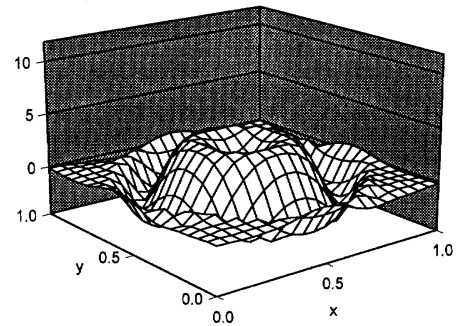

(7) $\mathrm{SUPG} / \mathrm{PSM}+\mathrm{CN}$

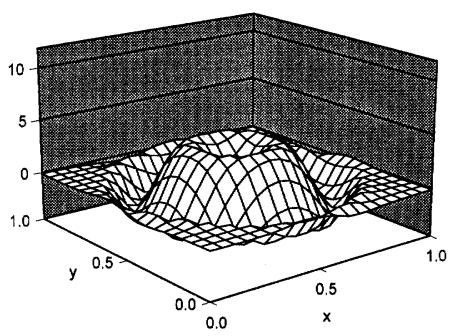

(9) SUPG/PSM+SI

Fig.5 Comparison of vorticity at $t=3$ 
Table 2 Comparison of computational time

\begin{tabular}{|l|r|r|r|r|}
\hline & $\begin{array}{r}\Delta t \\
\left(\Delta t_{\max }\right)\end{array}$ & Step & CPU time & $\begin{array}{r}\text { CPU time } \\
/ \text { step }\end{array}$ \\
\hline \hline MSI & 0.025 & 4000 & $116 \mathrm{sec}$ & $0.029 \mathrm{sec}$ \\
\hline SI & 0.025 & 4000 & $95 \mathrm{sec}$ & $0.024 \mathrm{sec}$ \\
\hline FI & 0.025 & 4000 & $5002 \mathrm{sec}$ & $1.251 \mathrm{sec}$ \\
\hline & $(5.0)$ & 20 & $62 \mathrm{sec}$ & $3.100 \mathrm{sec}$ \\
\hline CN & 0.025 & 4000 & $5202 \mathrm{sec}$ & $1.301 \mathrm{sec}$ \\
\hline & $(5.0)$ & 20 & $50 \mathrm{sec}$ & $2.500 \mathrm{sec}$ \\
\hline T6 & 0.025 & 4000 & $4944 \mathrm{sec}$ & $1.236 \mathrm{sec}$ \\
\hline & $(0.1)$ & 1000 & $1296 \mathrm{sec}$ & $1.296 \mathrm{sec}$ \\
\hline
\end{tabular}

期形状を良く保ってはいるものの, 著しい解の減衰がみ られる. また, Table 1に示すようにBTD 法と TaylorGalerkin 法 (TG 法)による結果は同値となることから， TG 法における Taylor 展開の 3 次の項の解析結果に与え る影響は非常に少ないと言える. また, SUPG/PSM 法 の時間積分に完全陰解法 (FI 法) や Crank-Nicolson 法 (CN 法), 一般的な淮陰解法 (SI 法) を適用した場合は解 が大幅に減衰している．また，Galerkin 法では安定な 計算が行えていないことが分かる. なお, SUPG/PSM 法と GLS 法により得られた解がほとんど一致している 理由は，先の定式化で示したように $\mathrm{Q} 1 / \mathrm{P} 0$ 要素を用い た場合は両手法間で導かれる項にさほど差がなく, GLS 法により付加される連続式の最小 2 乗項の影響が小さい ことによると言える.

Table 2に計算効率に対する検討として, SUPG/ PSM 法に適用した各時間積分法に関して，1).最大の 時間刻み幅 $\left.\Delta t_{\max }, 2\right) .1$ ステップあたりに要する計算時 間 (Silicon Graphics 社の Indy R4400による), 3). 無次 元時間 $t=100$ までに要する計算時間, を示す. このよ うな非定常問題での $\Delta t$ は解析精度にも影響を与えるた めに，ただ単に大きくすれば良いというものではない. しかし, 解析精度は別として総解析時間だけを考えた 場合は， $\Delta t$ を大きくとれる完全陰解法が他の陰解法や 淮陰解法と比べて有利であることが分かる. 一方で, 淮 陰解法は陰解法に比べ 1 ステップあたりの計算時間は 圧倒的に短いために, 完全陰解法と同程度の総解析時 間で済み, これも有効な時間積分法になり得る.また, 高精度な陰解法 $\mathrm{T} 6$ formulation は, $\Delta t_{\max }$ を大きく取 れないため, 陰解法の利点を生かしきれずに多大な解 析時間を必要とすることが分かる.

以上より, SUPG/PSM 法が散逸誤差の最も少ない高 精度な安定化有限要素法であることが確認できた。し かし，適用する時間積分法によって精度が大きく左右さ れ, 適切な時間積分法と組み合わせてはじめて高精度 な安定化法となる事も明らかとなった. 比較計算の結 果, 修正準陰解法 (MSI 法) と T6 formulation を適用し た場合に高精度な安定化法となることが示された。中
でも，MSI 法は計算効率に関しても十分に優れた時間 積分法と言え, SUPG/PSM 法と組み合わせる本手法 (SUPG/PSM+MSI 法)が高精度で計算効率に優れた手 法となることが明らかとなった。

\section{(2) Cavity 内流れ問題}

孤立渦問題において, SUPG/PSM法が最も散逸 誤差の少ない手法であることが示された。しかし， SUPG/PSM 法は用いる時間積分法によって, 減衰の 度合いが大きく異なることも分かった. そこで，ここで はより一般的なベンチマーク問題である Cavity 内流れ を取り上げ, SUPG/PSM 法に対して孤立渦問題で適用 した各種時間積分法を適用して, 解析精度の比較を行っ た.ここでは, 正方形 Cavity 内を 16 分割, 及び 32 分割 する二種類の不等分割した有限要素メッシュを用いて解 析を行うことにする. そしてSUPG/PSM+MSI法の解 析精度の信頼性，また同時に有限要素メッシュに対する 解の依存性について, Ghia らの結果 ${ }^{17)}$ と比較を行うこ とにより検討を行う. 計算条件として $R e=1000$, 時間 刻み幅 $\Delta t$ は 16 分割メッシュで $0.02,32$ 分割メッシュで は 0.01 として, 定常結果が得られるまで解析を行った。

Fig.6に, 定常状態での鉛直中心線上の水平方向流速

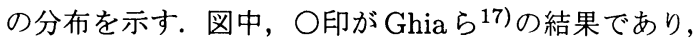
破線が 16 分割, 実線が 32 分割の結果である．図より, 孤立渦問題の結果と同様に, MSI 法及びT6 formulation により得られた結果は, 粗い有限要素メッシュを用い た場合でも，Ghiaらの結果と良い一致を示しているこ とが分かる. また，これらの結果はGLS 法による結果 とほぼ一致しており, 本手法と GLS 法との理論の等価 性を裏付けるものとなっている，また，SI法，FI法お よびCN 法は, 孤立渦問題の結果と同様に減衰が大きい 結果となっている.

以上の結果より, Cavity 内流れ問題においても提案す るSUPG/PSM+MSI 法の有効性が確認された。また, 孤立渦問題 (初期条件で強制的に対流を与える初期值問 題)で散逸誤差の大きい手法は Cavity 内流れ問題 (境界 条件で強制的に対流を与える境界值問題)においても減 衰の大きな結果を与えることが明らかとなった.

\section{(3) 3 次元円柱周りの高 Reynolds 数域に至る流れ}

孤立渦問題及びCavity 内流れ問題という代表的なべ ンチマーク問題において, 本手法 (SUPG/PSM+MSI 法)の有効性が明らかになった. そこでここでは，3次 元高 Reynolds 数流れ問題への有効性の確認として, 円 柱周りの流れを取り上げ, 計算によって得られた特性值 と実験值 ${ }^{20)}$ との比較を行った. また, あわせて 2 次元 解析と 3 次元解析との結果の差異についても検討した。

2 次元解析に用いる有限要素メッシュはFig.7 に示す 


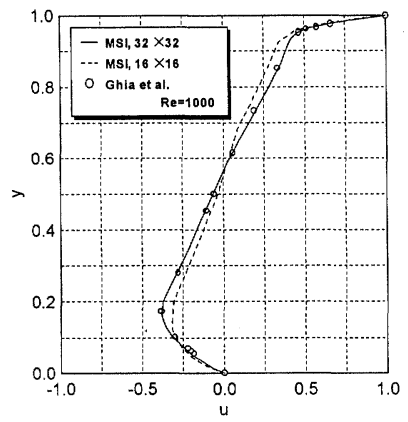

(a) present method(SUPG/PSM+MSI)

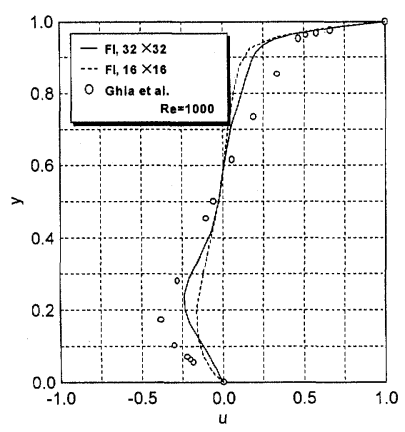

(d) SUPG/PSM+FI

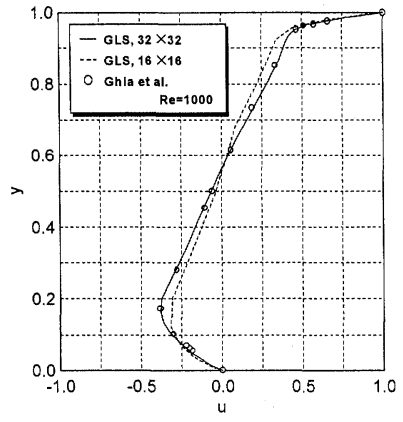

(b) GLS

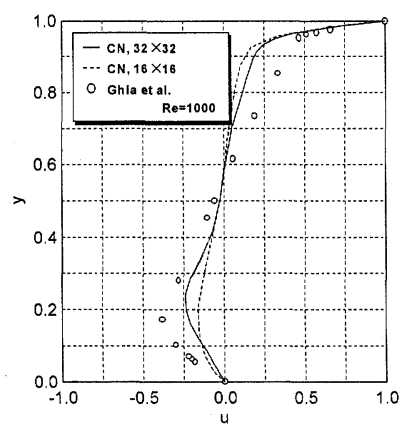

(e) SUPG/PSM+CN

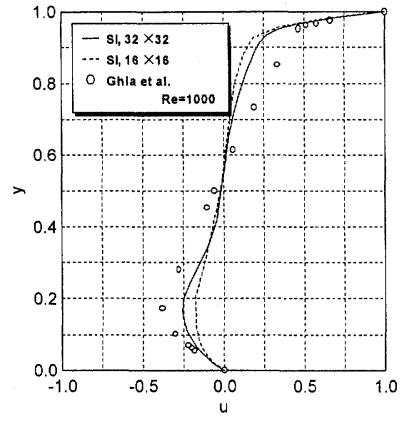

(c) $\mathrm{SUPG} / \mathrm{PSM}+\mathrm{SI}$

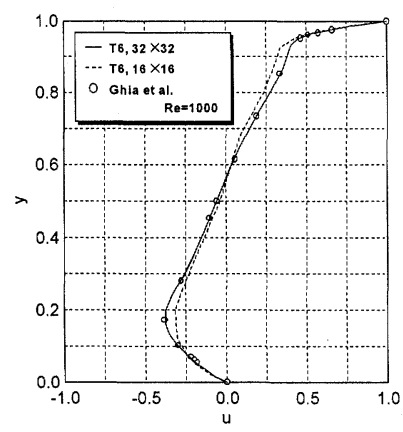

(f) SUPG/PSM+T6

Fig.6 Comparison of computed horizontal velocity at central section

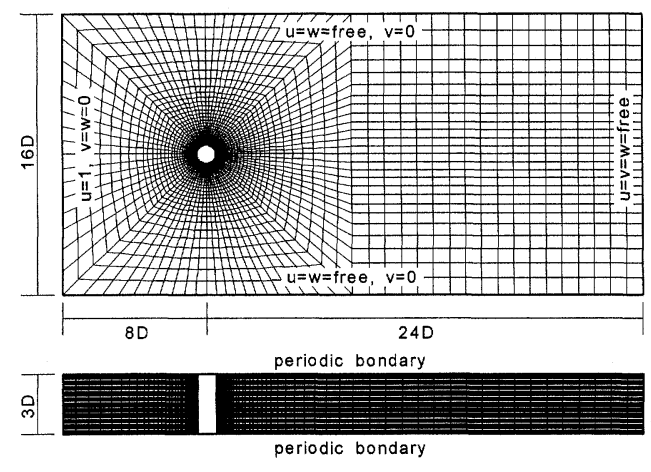

Fig.7 Finite element idealization

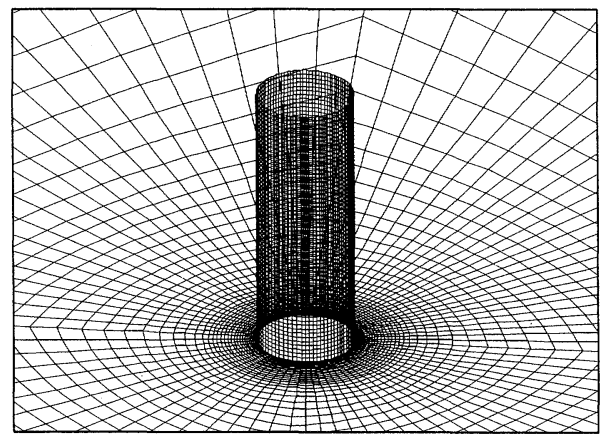

Fig.8 Finite element mesh around a cylinder
ような節点総数 4,270 , 要素総数 4,166 のものである. 周 方向に 86 分割, 半径方向に 45 分割したものであり, 半 径方向の最小メッシュ幅 $h_{\min }$ は円柱の直径 $D$ に対して $0.006 D$ となっている. 3 次元解析を行う際には, Fig.8 のように 2 次元の有限要素メッシュをスパン方向に長さ $H=3 D$ として 60 等分割したものを用いた. なお，境界 条件についても, Fig.7に示している. 閉塞率を含む水平 方向及び鉛直方向の解析領域の設定については, その差 異が計算結果に影響を及ぼさないことを確認して決定し
た ${ }^{18)}$. スパン方向のメッシュ幅は $0.05 D$, 節点総数は $4,270 \times 61=260,470$, 要素総数は $4,166 \times 60=249,960$ と なっている. 計算条件として, $R e=10^{2} \sim 10^{6}, \Delta t=0.005$ とし，すべて同一の有限要素メッシュを用いて解析を 行った. なお， 3 次元解析の初期值としては 2 次元計算 において十分発達し, 準定常性が得られている解析結果 $(t=150)$ を60層に積み重ねたものを用いた．またより 効率よく解析を行うために計算の初期 $(150 \leq t \leq 151)$ に撹乱を加えることとし，円柱を軸方向に速度 

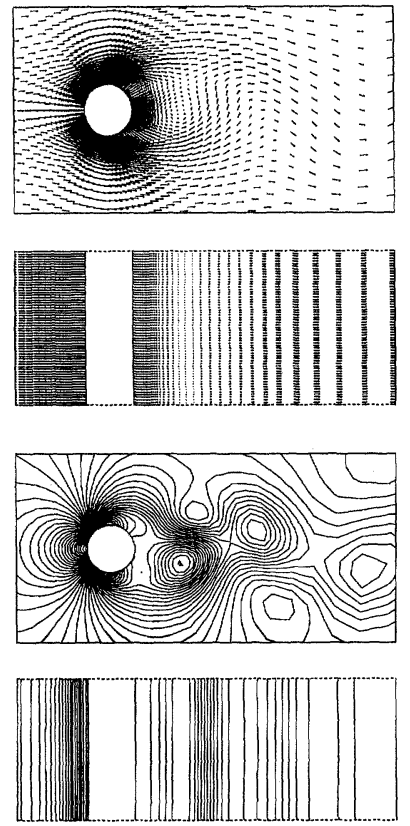

(a) $R e=10^{2}$
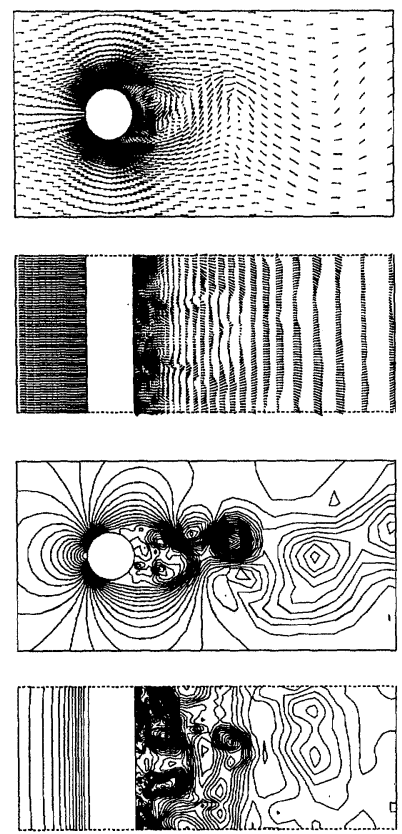

(d) $R e=10^{4}$
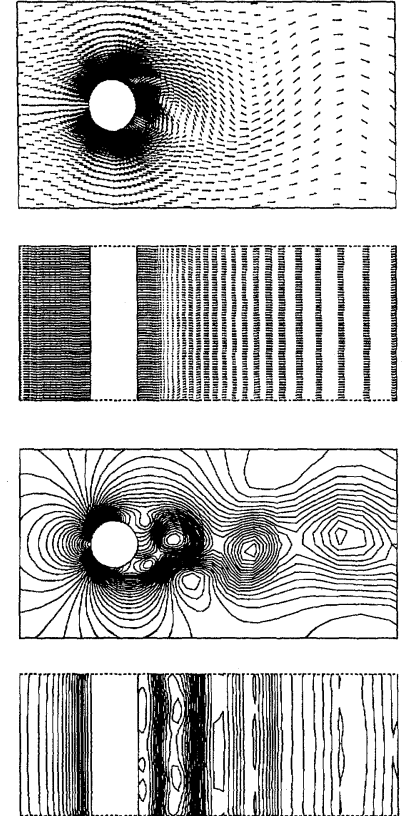

(b) $R e=10^{2.5}$
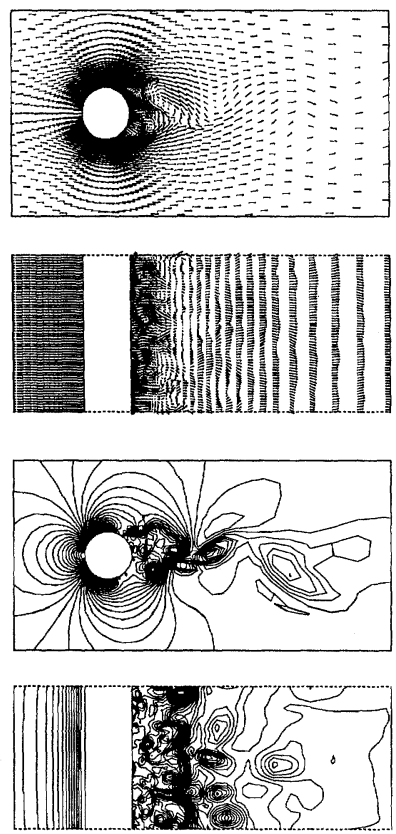

(e) $R e=10^{5}$
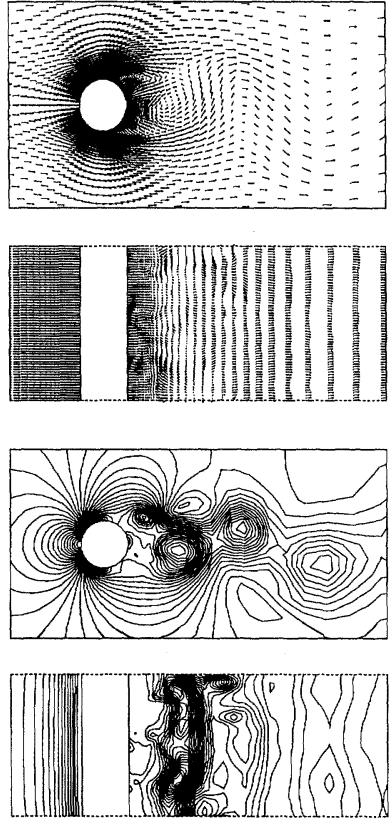

(c) $R e=10^{3}$
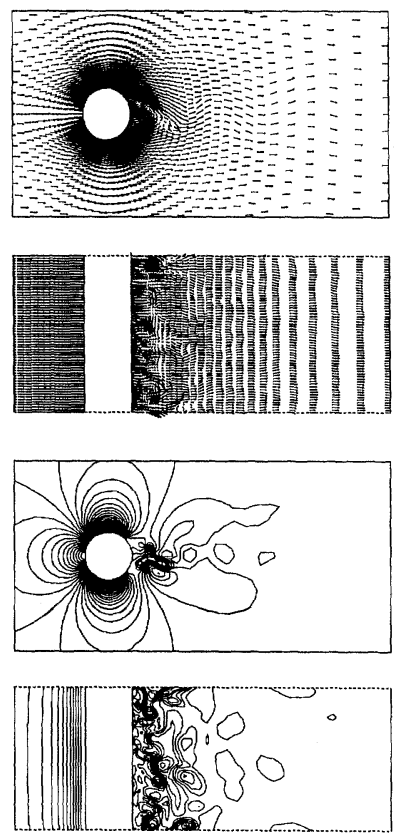

(f) $R e=10^{6}$

Fig.9 Computed velocity and pressure at central section 


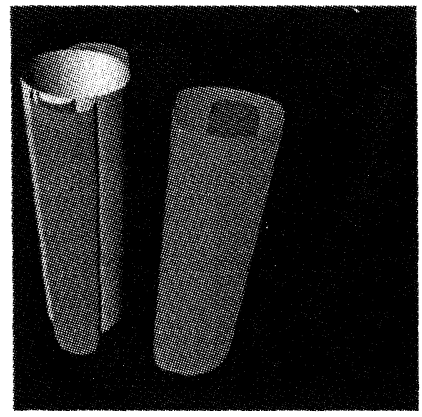

(a) $R e=10^{2}$

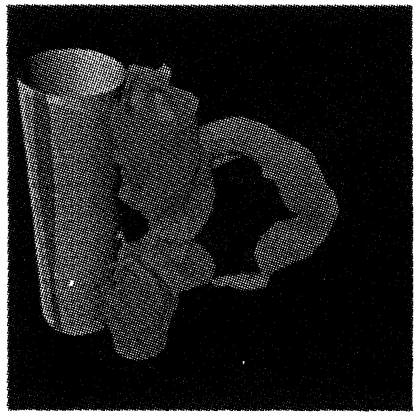

(d) $R e=10^{4}$

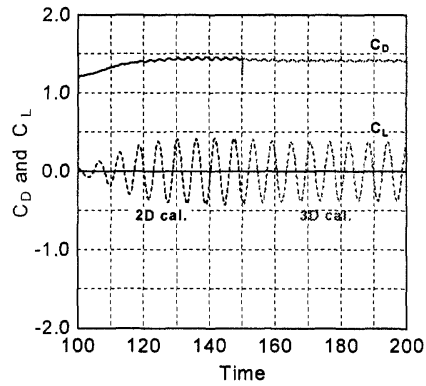

(a) $R e=10^{2}$

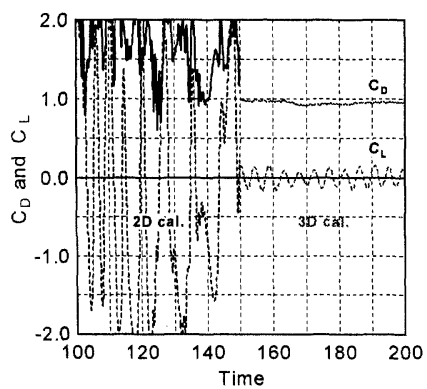

(d) $R e=10^{4}$

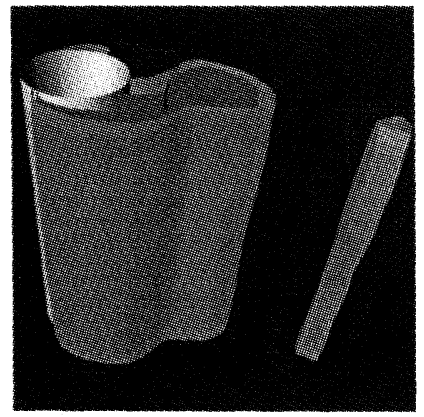

(b) $R e=10^{2.5}$

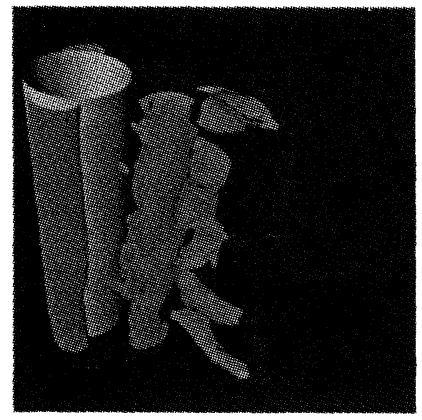

(e) $R e=10^{5}$

Fig.10 Iso-contour of pressure

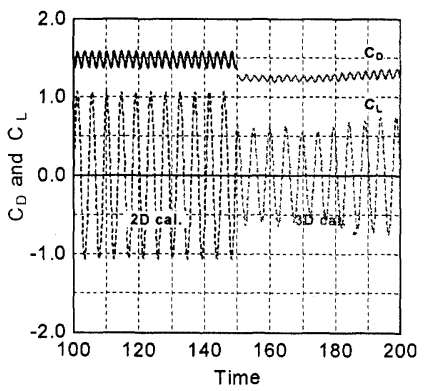

(b) $R e=10^{2.5}$

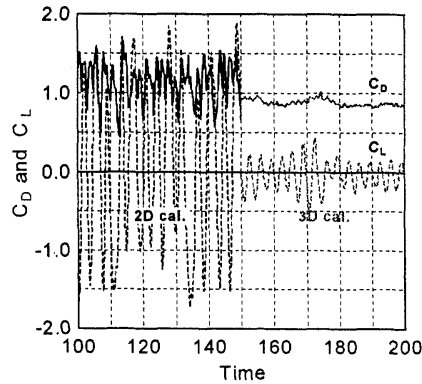

(e) $R e=10^{5}$

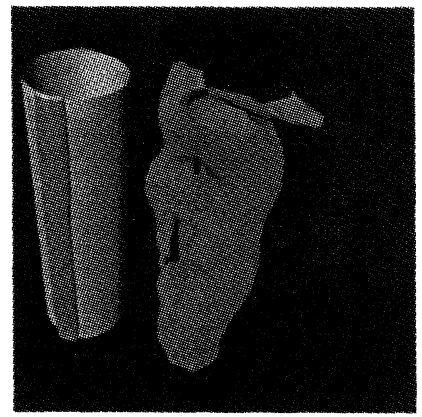

(c) $R e=10^{3}$

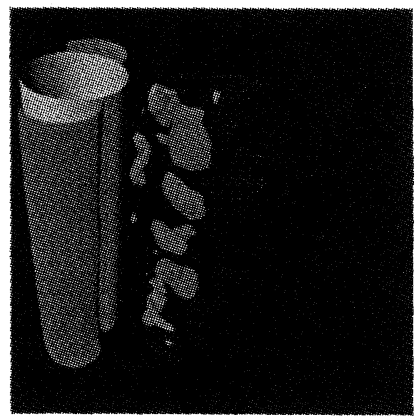

(f) $R e=10^{6}$

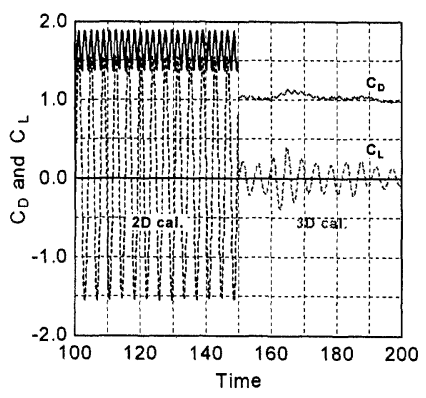

(c) $R e=10^{3}$

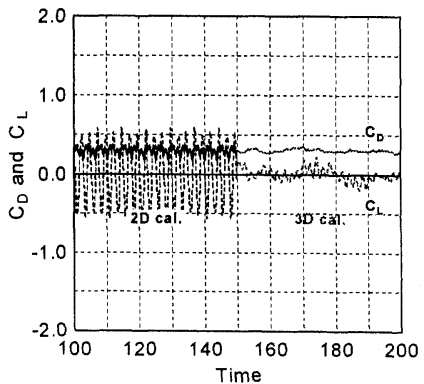

(f) $R e=10^{6}$

Fig.11 Time history of drag coefficient and lift coefficient 


$$
w(t)=0.02 \times(1-\cos (2 \pi t))
$$

で動かした.これにより，より早く 3 次元性を捉えるこ とができ計算時間の短縮が図れた ${ }^{19)}$ 。 なお，円柱のス パン方向には周期境界条件

$$
u_{i}(*, *, z+H, *)=u_{i}(*, *, z, *)
$$

を課している.

Fig.9に 3 次元解析結果として, 中心断面 $(z=1.5$, $y=0.0)$ における流速ベクトル, 圧力分布を示す. また, その際の圧力の等值面図を Fig.10に, 抗力係数 $C_{D}$, 揚 力係数 $C_{L}$ の時刻歴を Fig.11に併せて示している (2次 元解析により得られた結果 $(100 \leq t \leq 150), 3$ 次元解析 により得られた結果 $(150 \leq t \leq 200))$. これらの結果よ り, $R e=10^{2}$ では 3 次元性の見られない完全な 2 次元流 れとなっており, 抗力, 揚力係数も 2 次元, 3 次元解析 の間でほとんど同値となっているのが分かる.しかし， $R e=10^{2.5}$ より若干の 3 次元性が現れ始め, $R e=10^{3} \sim 10^{4}$ では 3 次元性が強まるとともに, 大幅な抗力係数, 揚力 係数の変動振幅の低下が見られる.これは渦構造に 3 次 元性が現れることに起因するエネルギーの縦方向への 散逸により，2 次元解析で現れる大規模渦が大幅に減衰 していることが主な原因と考えられる. Re $=10^{5}$ からは 渦のスケールがかなり小さくなるとともに, 揚力係数 の振動振幅の大幅な低下は見られるが抗力係数の低下 があまり起こらないようになる. $R e=10^{6}$ では渦の剥離 点が明らかに後方に移動しており, 渦のスケールに合 わせて後流幅が狭まっているのが伺える.

Fig.12に各 Reynolds 数における抗力係数の平均值 と実験値 ${ }^{20)}$ との比較を示す. $R e=10^{3} \sim 10^{4}$ での結果を 見ると先に示したよう 2 次元解析と 3 次元解析との間 で顕著な差異が見られ, 2 次元解析では実験值との一 致は得られていない.しかし， 3 次元解析を行うこと により抗力係数が大幅に減少し実験值と良い一致を示 していることが分かる. 本解析で用いた有限要素メッ シュは $R e=10^{4}$ 程度までは境界層を分割できており, こ の結果, $R e=10^{4}$ 程度までは 3 次元解析を行った場合に, 実験值との比較においても良く対応したものと考える. また, Fig.13のStrouhal 数の平均値の実験值との比較 においても, $R e=10^{4}$ 程度までは実験值と定量的に良い 一致を示していることが分かる. $R e=10^{5} \sim 10^{6}$ の超臨 界域での Reynolds 数において, 解析結果をより定量的 に評価するためには, 境界層をより細かく分割した有 限要素メッシュを用いるか, もしくは乱流モデルの導 入等の方策が必要となると言える. しかし, 抗力係数 の低下現象やStrouhal 数の増加現象などは明確に捉え られており, 定性的には実験值と良い一致を示してい る. なお, 計算時間は 1 ステップあたり約 30 秒 (DEC

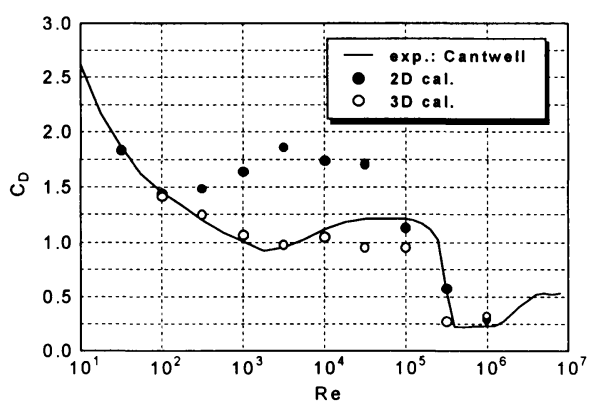

Fig.12 Comparison of drag coefficient

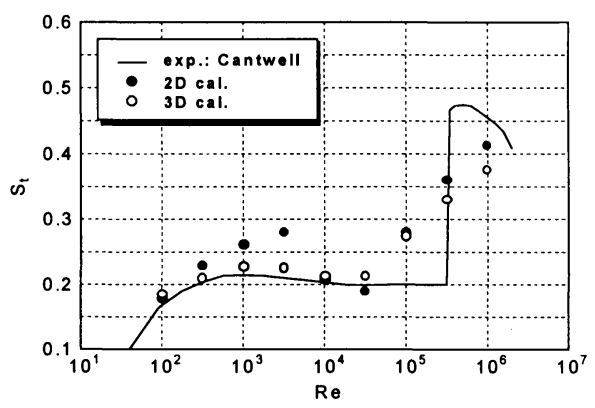

Fig.13 Comparison of Strouhal number

Alpha21164(300MHz)) であった.

\section{7. おわりに}

本論文では, 低次の混合補間要素である, 流速 双 1 次/圧力区分 0 次で補間する $\mathrm{Q} 1 / \mathrm{P} 0$ 要素を用い た, 非圧縮粘性流れ解析のための安定化有限要素法 (SUPG/PSM+MSI 法) の提案を行った.そして，本手 法の数值流体解析手法としての有効性を示すために, 本 手法と他の安定化有限要素法との比較を定式化及び解 析結果の両面から行い，また時間積分法に関しても様々 な方法を取り上げ比較検討を行った．本論文により得 られた結論を示すと，以下のようになる.

(1) SUPG 法と圧力安定化行列を併用する SUPG/PSM 法は, 代表的な安定化有限要素法である GLS法や SUPG/PSPG 法と理論的に等価であり，また，それら の手法と比べてより簡便に安定化を図れる手法である ことが示された.

(2) SUPG/PSM 法の時間積分法に修正準陰解法を適用 する方法 (SUPG/PSM+MSI 法)が他の時間積分法を適 用寸る場合と比べて高精度でかつ計算効率が良いこと が明らかになった．また，有限要素メッシュへの依存性 が少なく，粗い有限要素メッシュを用いた場合でも他 の手法に比べて高精度である事も確認された。 
（3）係数行列の作成に解析的積分法を, また圧力ポア ソン方程式の解法にはElement by Element 共役勾配法 (SCG 法)を用いることにより, 大幅な省メモリー化と 高速化が実現された。

(4) 円柱周り流れの解析において, 本手法の 3 次元問題 への適用性と有効性が示された. 特に, メッシュ分割 が境界層を表現している $R e=10^{4}$ 程度までは得られた特 性値は実験値と定量的にもよい一致を示した。

謝辞： 本研究を進めるにあたり，(株)NK-EXA 水上 昭氏には大変貴重なご意見を頂きました。ここに記し て感謝の意を表します.

\section{参考文献}

1) Hughes, T.J.R., Franca, L.P. and Balestra, M. : A new finite element formulation for CFD : V. Circumventing the Babuška-Brezzi condition : A stable Petrov-Galerkin formulation of the Stokes problem accommodating equal-order interpolations, Comput. Methods Appl. Mech. Engrg., 59, pp.85-99, 1986.

2) Hughes, T.J.R. and Franca, L.P. : A new finite element formulation for CFD:VII. The stokes problem with various well-posed boundary conditions: Symmetric formulations that converge for all velocity/pressure spaces, Comput. Methods Appl. Mech. Engrg., 65, pp.85-96, 1987.

3) 渡辺浩志, 久田俊明 : 混合型有限要素解の安定条件の数値 解析，日本機械学会論文集 (A 編), 61 巻 583 号, pp.168$175,1995$.

4) Brooks, A.N. and Hughes, T.J.R. : Streamline upwind / Petrov-Galerkin formulations for convection dominated flows with particular emphasis on the incompressible Navier-Stokes equations, Comput. Methods Appl. Mech. Engrg., 87, pp.364-384, 1991.

5) Tezduyar, T.E., Mittal, S. and Shih, R. : Timeaccurate incompressible flow computations with quadrilateral velocity-pressure elements, Comput. Methods Appl. Mech. Engrg., 79, pp.71-86, 1990.

6) Silvester, D.J. and Kechkar, N. : Stabilized bilinearconstant velocity-pressure finite elements for the conjugate gradient solution of the stokes problem, Comput. Methods Appl. Mech. Engrg., 79, pp.71-86, 1990.

7) 水上昭 : $\mathrm{Q}_{1}-\mathrm{P}_{0}$ 要素による FEM 流れ解析のための安定 化行列, 第 8 回数值流体シンポジウム論文集, pp.647-650, 1994.

8) Hughes, T.J.R., Franca, L.P. and Hulbert, G.M. : A new finite element formulation for CFD : VIII. The Galerkin-least-squares method for advective-diffusive equations, Comput. Methods Appl. Mech. Engrg., 73, pp.173-189, 1989.

9) Franca, L.P. and Frey, S.L. : Stabilized finite element methods: II. The incompressible Navier-Stokes equations, Comput. Methods Appl. Mech. Engrg., 99, pp.209-233, 1992.
10) Tezduyar, T.E., Mittal, S., Ray, S.E. and Shih, R. : Incompressible flow computations with stabilized bilinear and linear equal-order-interpolation velocitypressure elements, Comput. Methods Appl. Mech. Engrg., 95, pp.221-242, 1992.

11) Donea, J. : A Taylor-Galerkin Method for convective transport problems, Int. J. Numer. Methods Engrg., 20, pp.101-119, 1984.

12) Gresho, P.M. and Chan, S.T. : On the theory of semiimplicit projection methods for viscous incompressible flow and its implementation via a finite element method that also introduces a nearly consistent mass matrix, Part 1: Theory, Part 2: Implementation, Int. J. Numer. Methods Fluids, 11, pp.587-620, pp621-659, 1990.

13) Gresho, P.M., Chan, S.T., Lee, R.L. and Upson, U.D. : A modified finite element method for solving the time-dependent incompressible Navier-Stokes equations, Part 1: Theory, Part 2: Applications, Int. J. Numer. Methods Fluids, 4, pp.557-598, pp619-640, 1984.

14) Mizukami, A. : Integration formulas for a 4-node isoparametric element, Comput. Methods Appl. Mech. Engrg., 59, pp.111-121, 1986.

15) 水上昭 : Element-by-Element PCG 法のベクトル化と 流れ解析への応用, 第 2 回計算力学シンポジウム論文集, pp.1-6, 1988.

16) Shakib, F. and Hughes, T.J.R. : A new finite element formulation for CFD : IX. Fourier analysis of space-time galerkin/least-squares algorithms, Comput. Methods Appl. Mech. Engrg., 87, pp.35-58, 1991.

17) Ghia, U., Ghia, K.N. and Shin, C.T. : High-Re solutions for incompressible flow usig the NavierStokes equations and a multigrid method, J. Comput. physics, 48, pp.387-411, 1982.

18）原田太一, 猪股涉, 樫山和男 : 安定化有限要素法による非 圧縮粘性流れ解析における適切な解析領域設定の検討, 土 木学会第 52 回年次学術講演会概要集, $1-\mathrm{B}, \mathrm{pp} .8-9,1997$.

19）茂里一紘, 土井康明, 上岡孝志：2次元円柱まわりの 3 次元流れの数值シュミレーション, 第 4 回数值流体シン ポジウム報文集, pp.503-506, 1990.

20) Cantwell, B. and Coles, D. : An experimental study of entrainment and transport in the turbulent near wake of a circular cylinder, J. Fluid Mech., 136, pp.321-374, 1983.

21) Kalro, V. and Tezduyar, T. : Parallel finite element computation of 3D incompressible flows on MPPs. In Habashi, W. , editor, Solution Techniques for LargeScale CFD Problems., 1995.

22) Tamura, T. and Kuwahara, K. : Direct finite difference computation of turbulent flow around a circular cylinder, Proc. Int. Symp. of Comput. Fluid Dynamics, Nagoya, pp.701-706, 1989.

23）猪股涉, 樫山和男 : 安定化有限要素法による非圧縮性流れ 解析, 第 10 回数值流体シンポジウム論文集, pp.334-335, 1996.

24) Inomata, W. and Kashiyama, K. : Stabilized finite element method for high Reynolds number flows, The 2nd Asian Comput. Fluid Dynamics Conf., Tokyo, pp.313-318, 1996. 


\section{STABILIZED FINITE ELEMENT METHOD FOR INCOMPRESSIBLE VISCOUS FLUID FLOWS USING LOW-ORDER MIXED INTERPOLATIONS}

\section{Kazuo KASHIYAMA and Wataru INOMATA}

A stabilized finite element method based on the Q1/P0 element is presented for the analysis of incompressible viscous fluid flows. A presssure stabilization matrix(PSM) for the Q1/P0 element is introduced to avoid the occurrence of the checkerboard pressure mode. Also, SUPG formulation is employed to improve the numerical stability and accuracy. For the temporal discretization, a modified semi-implicit scheme(MSI) is applied. The pressure poisson equation system is solved by the Element-by-Element conjugate gradient method. The present method is shown to be an accurate and efficient tool for the analysis of incompressible viscous fluid flows. 